\title{
Cost Of Capital, Corporate Tax Plannings, And Corporate Social Responsibility Disclosure
}

\author{
Adhitya Jati Purwaka', Amrie Firmansyah ${ }^{2}$, Resi Ariyasa Qadri ${ }^{3}$, Agung Dinarjito ${ }^{4}$, \\ and Zef Arfiansyah ${ }^{5}$ \\ ${ }^{1,2}$ Program Diploma IV Akuntansi Sektor Publik, Politeknik Keuangan Negara STAN \\ ${ }_{3,4,5}$ Program Diploma III Akuntansi, Politeknik Keuangan Negara STAN \\ Email Address: \\ jati.adhitya@gmail.com, amrie@pknstan.ac.id, resi.ariyasa@gmail.com, agungdije@gmail.com, \\ zef.arfiansyah@pknstan.ac.id
}

\begin{abstract}
This study aims to determine the effect of tax management activities on the cost of capital and the role of social responsibility disclosure in moderating its impact. This study employs secondary data from financial statement data, stock price information, and 10-year government bond yields. The data was obtained from the websites www.idx.co.id, www.idnfinancials.com, www.finance.yahoo.com, and www.bloomberg.com. Using purposive sampling, the research sample is from manufacturing companies listed on the Indonesia Stock Exchange from 2016 to 2020, obtaining 325 observations. Data were analyzed employing multiple linear regression for panel data. This study indicates that tax avoidance and tax aggressiveness are not associated with the cost of capital, while tax risk is negatively related to the cost of capital. Corporate social responsibility disclosure does not succeed in moderating the effect of tax avoidance and tax aggressiveness. Still, it succeeds in moderating the association between tax risk and cost of capital.
\end{abstract}

Keywords: firm risk, tax avoidance, tax aggressiveness, tax risk, sustainability.

\begin{abstract}
Abstrak: Penelitian ini bertujuan untuk menguji pengaruh penghindaran pajak, agresivitas pajak, dan risiko pajak terhadap biaya modal dan peran pengungkapan tanggung jawab sosial dalam memoderasi hubungan tersebut. Penelitian ini menggunakan data sekunder berupa data laporan keuangan dan informasi harga saham, serta imbal hasil obligasi pemerintah bertenor 10 tahun. Data diperoleh dari website www.idx.co.id, www.idnfinancials.com, www.finance.yahoo.com, dan www.bloomberg.com. Dengan menggunakan purposive sampling, sampel penelitian dengan perusahaan manufaktur yang terdaftar di Bursa Efek Indonesia dari tahun 2016 sampai dengan tahun 2020, diperoleh 325 observasi. Data dianalisis menggunakan regresi linier berganda untuk data panel. Penelitian ini menunjukkan bahwa penghindaran pajak dan agresivitas pajak tidak berhubungan dengan biaya modal, sedangkan risiko pajak berhubungan negatif dengan biaya modal. Pengungkapan tanggung jawab sosial perusahaan tidak berhasil memoderasi pengaruh penghindaran pajak dan agresivitas pajak, tetapi berhasil memoderasi hubungan antara risiko pajak dan biaya modal.
\end{abstract}

Kata kunci: risiko perusahaan, penghindaran pajak, agresivitas pajak, risiko pajak, keberlanjutan. 


\section{INTRODUCTION}

The company aims to increase the firm value (Firmansyah and Purnama, 2020). The optimal funding structure can reflect one indicator that determines the firm value. The optimal funding structure can be seen from presenting the company's use of debt and equity. The company can balance the benefits and costs of operating capital, especially from debt. The use of debt in the capital structure can lead to tax savings in the form of a tax shield where interest payments made by companies are fiscal costs that can reduce taxable income (Indriyani, 2017). The use of debt proportions in the company's funding structure will create a tax shield that can increase the value of a company (Jananto and Firmansyah, 2019). Thus, the company requires debt in its funding structure to maximize its value. However, the use of debt will increase financial risk in the form of financial distress.

Thus, companies need to balance debt and equity at the optimal point to avoid the default risk (Firmansyah et al., 2021). Funding is closely related to the risk borne by the provider of funds. The reward represents the risk involved in providing funds to the company. Assessment of company risk is an important aspect for fund providers in funding decisions (Febrininta and Siregar, 2014). Investors set a high rate of return to risky companies as compensation for the risk of providing funds to the company. The rate of return is a reference point for companies setting costs to obtain funding, commonly referred to as the cost of capital in financial management terms. The cost of capital consists of the cost of debt and the cost of equity, both of which are costs that the company must incur in obtaining funding from debt, issuing bonds (debt) and selling shares (equity) (Febrininta and Siregar, 2014). One form of the cost of capital is reflected in the valuation of the company's shares. The cost of capital is implied in the internal rate of return that equates the company's stock price with the present value of the future cash flows that investors expect (Sikes and Verrecchia, 2020).

Companies that engage in policies are at risk of causing more demands from investors to increase expected returns. Companies charge a higher cost of capital through rising interest costs, dividends and decreasing stock prices beyond the expected rate of return to persuade risk-averse investors to place their funds with the company. On the other hand, the cost of capital is a determining factor in the optimal funding structure to increase firm value. The cost of capital that is too high will erode the return generated from the company's investment originating from external funding. The company will attempt to obtain a low cost of capital to secure the return from the investment activities that the company determines. Companies that make tax savings to maximize firm value will increase debt rather than equity in their funding structure (Firmansyah et al., 2020). Companies use debt to obtain a lower cost of capital because debt is lower than equity due to tax effects. However, the benefits of increasing the debt ratio are not always profitable for the company (Brigham and Houston, 2019). The credit rating reflects the company's financial health condition so that a decrease in credit rating can increase the cost of debt (Jiraporn et al., 2014). In addition, the use of debt will increase access to information for creditors to make investment decisions. This condition causes information asymmetry between creditors and common stockholders in the capital market. Common stockholders who have access to less information will increase the expected rate of return, which causes an increase in the cost of equity. The higher rate of return reflects the risk insured by common stockholders who are 
not better informed than creditors (e.g., liquidation information) (Yeh et al., 2020). Therefore, research on the determinants of the cost of capital is important to be investigated.

Research on the determinants of the cost of capital, the cost of debt and equity, generally involves variables that describe management policies, such as earnings management (Atmaja, 2020; Febrininta and Siregar, 2014; Febriyanto and Firmansyah, 2018; Kim and Charlie, 2013), asymmetric information (Nuryatno et al., 2019), corporate social responsibility disclosure (Firmansyah et al., 2021; Suto and Takehara, 2017; Yeh et al., 2020), corporate governance (AlHares, 2020; Firmansyah et al., 2021), tax avoidance (Chun et al., 2019; Febriyanto and Firmansyah, 2018; Goh et al., 2016; Kovermann, 2018; Shin and Woo, 2018; Sikes and Verrecchia, 2020; Wardani et al., 2019), tax risk (Hutchens \& Rego, 2017; Kovermann, 2018). In addition, the determinants of the cost of capital can be seen from the company's external perspective, such as vulnerability to climate change which increases financial constraints (Kling et al., 2021). The manager's policy influences the company's cost of capital in carrying out the company's business activities. Tax avoidance is one of the managers' policies in corporate tax planning. Previous research examined the effect of tax avoidance on the cost of capital. Tax avoidance is a form of management policy to obtain tax savings that can increase risk and have implications for improving the cost of capital. The cost of capital is closely related to the company's funding structure decisions, although it is not limited to these decisions. Tax avoidance activities carried out by companies are considered risky from the investors' perspective. It can increase the expected rate of return and have implications for the higher cost of capital (Hutchens and Rego, 2017; Shin and Woo, 2018; Sikes and Verrecchia, 2020). Research on tax avoidance as a determinant of the cost of capital is still conducted partially on the cost of equity or the cost of debt. (Kovermann, 2018) examined the effect of tax avoidance and tax risk on the cost of debt. The result found that creditors consider tax avoidance to increase the company's cash flow, which can fulfill debt repayments and repayments, thereby reducing the cost of debt. This result contradicts (Shin and Woo, 2018), who found that tax avoidance has a positive effect on increasing the cost of debt. The test result suggests that tax avoidance is considered a risk factor so that creditors demand higher returns.

Furthermore, (Goh et al., 2016) examined the effect of tax avoidance on the firm's cost of equity and found that investors set a low cost of equity due to the positive cash flow effect of the firm's tax avoidance. This result is in line with the findings of (Chun et al., 2019), who found tax avoidance has a negative effect on the cost of equity in countries that have strong investor protection but has a positive impact on countries with low investor protection through the determination of a higher market risk premium by investors. Furthermore, (Sikes and Verrecchia, 2020) found that many companies that do tax avoidance in the aggregate, namely the company's overall tax payments divided by the company's overall pre-tax income, increase the company's cost of capital. Aggregate tax avoidance increases a firm's covariance risk, and thus its cost of capital increases by expanding the market risk premium. It is in line with (Febriyanto and Firmansyah, 2018), who found that tax avoidance leads investors to bear the risk of increasing uncertainty in their investment results which causes an increase in the company's cost of equity. These results illustrate that there are still inconsistencies in research results on the effect of tax avoidance on the cost of capital.

This study examines tax avoidance on the cost of capital. This study also includes tax aggressiveness and tax risks. The company seeks to minimize the tax expenses, not limited to tax avoidance activities in general. (Lietz, 2013) developed a conceptual framework for 
tax planning activities found a difference between tax avoidance and tax aggressiveness. The practice of tax avoidance does not distinguish between legal procedures and methods of doubtful legality (grey-scaled). At the same time, tax aggressiveness refers to a more aggressive level of tax avoidance, specifically by exploiting the exploited gaps in taxation rules (a grey area). Tax aggressiveness creates tax risk, which is reflected in the volatility of tax payments. (Guenther et al., 2017) defined tax risk as to the uncertainty of future tax payments and penalties related to the company's current tax position. Companies that engage in tax aggressiveness activities are exposed to a higher risk of uncertainty associated with the probability of paying taxes in the future. Concerning tax aggressiveness, aggressive tax avoidance results in a higher risk of cash flow uncertainty in tax payments which investors perceive as riskier. (Kubick and Lockhart, 2017) found that tax aggressiveness impacts the debt contract structure of firms with shorter maturities. Creditors employ renegotiation of shorter debt maturities as a tool to manage credit risk related to corporate tax aggressiveness, thus assessing tax aggressiveness as risky for creditors. It is in line with the findings of (Hutchens and Rego, 2017), who found that more aggressive tax avoidance is considered dangerous by investors, thereby increasing its cost of equity. Therefore, aggressive tax avoidance by companies impacts the higher cost of capital. Research on tax risk on the cost of capital produces consistent findings, increasing the company's cost of capital. The test of tax risk on the cost of debt was carried out by (Kovermann, 2018), who found that tax risk increases the company's cost of debt.

(Kovermann, 2018) placed tax risk as moderating the relationship between tax avoidance and the cost of debt and found that the effect of tax avoidance is highly dependent on the relationship between tax avoidance and tax risk. The impact of tax avoidance which was originally negative, becomes positive on the cost of debt if moderated by tax risk. Meanwhile, in a separate test of tax risk, the result is the same, namely increasing the cost of debt. Furthermore, (Hutchens and Rego, 2017) found that tax risk positively affects the cost of equity. High tax risk is described as high after-tax cash flow volatility.

Based on the literature review, the previous tests only partially involved the cost of capital, either the cost of debt or the cost of equity. The concept of tax aggressiveness is considered as having something in common with tax risk related to the uncertainty of the company's after-tax cash flows (Hutchens and Rego, 2017; Kovermann, 2018). The condition of companies that can maintain persistently low tax payments illustrates that companies can carry out aggressive tax avoidance without increasing tax risk, as reflected in stable tax payments (Lietz, 2013). Therefore, the concept of tax aggressiveness and tax risk can be viewed from a different perspective, so testing involving these three variables is compelling, especially since this test has never been conducted involving company data in Indonesia.

Furthermore, this study includes the role of corporate social responsibility (CSR) as a moderator in testing the effect of tax avoidance, tax aggressiveness and tax risk on the cost of capital. Corporate social responsibility aims to realize sustainable economic development to improve the quality of life and the environment that is beneficial to the local community and society in general as well as the company itself in the context of establishing a harmonious, balanced and appropriate corporate relationship with the environment, values, norms and culture of the local community (Deegan, 2014). Stakeholder theory states that corporate responsibility is not limited only to the company's welfare (shareholders) (Deegan, 2014). The company has social responsibility by considering the interests of all parties 
affected by the company's actions or policies (stakeholders) (Pradipta and Supriyadi, 2015). Stakeholder theory has a field of moral ethics which states that all stakeholders have the right to be treated fairly by the company (Rokhlinasari, 2015). CSR disclosure implies the company's ongoing commitment to act ethically to maintain fair relationships with stakeholders. In theory, social responsibility disclosure reduces investors' perception of company risk. Investors consider companies that disclose social responsibility to avoid unethical behavior such as tax avoidance. Based on this view, the company should get a lower cost of capital.

(Yeh et al., 2020) found that high social responsibility performance can lower the company's cost of debt. (Jiraporn et al., 2014) found that more responsible companies enjoy favorable credit ratings. A high credit rating gives companies flexibility in access to finance in the capital market, making it easier to make loans with low debt costs. Furthermore, (Suto and Takehara, 2017) found that corporate social responsibility disclosure negatively affects the cost of equity, which is moderated by institutional ownership. CSR disclosure is considered non-financial information that can reduce information asymmetry. More effective communication due to lower information asymmetry further limits the potential for managerial opportunism and builds stakeholder trust (Pérez, 2015). Therefore, a positive impression is more likely to emerge from companies that disclose their social responsibility than those that do not. (Firmansyah and Estutik, 2020) found that corporate social responsibility disclosure is negatively associated with tax aggressiveness.

Furthermore, companies involved in aggressive tax policies are considered socially irresponsible (Firmansyah and Estutik, 2020). Corporate social responsibility provides a control mechanism so that companies comply with the principles of responsible behavior, thereby eliminating the opportunity for companies to hide aggressive tax avoidance (Whait et al., 2018). Based on stakeholder theory, companies pay taxes fairly as corporate ethics to the government and other taxpayers (Firmansyah and Estutik, 2020). Companies that disclose their socially responsible activities will reduce their tax avoidance activities, including aggressive tax avoidance, to maintain an ethical view of the company in the eyes of all parties affected by company policies. To meet stakeholder expectations, fulfilling tax obligations is a form of corporate social responsibility activities. On the other hand, corporate social responsibility disclosure can reduce asymmetric information between managers and investors. It can change the perception of investors' risk to the company, which has implications for setting a lower rate of return so that the cost of capital that the company must issue becomes lower.

This study also employs control variables that are leverage, firm size and profitability, which are confirmed to affect the cost of capital, both the cost of debt and the cost of equity (Febriyanto and Firmansyah, 2018; Goh et al., 2016; Kovermann, 2018; Shin and Woo, 2018). (Kovermann, 2018) argued that the leverage ratio positively affects the cost of capital with the assumption that the higher the company's debt will increase the company's financial burden. In addition, (Goh et al., 2016) stated that leverage functions in controlling the company's capital structure. Larger company size has more assets that can serve investors, so that company size is expected to influence negatively (Kovermann, 2018). Profitability is expected to have a negative effect because high corporate profits describe the condition of a company that can serve investors (Kovermann, 2018). 


\section{THEORETICAL REVIEW}

Tax avoidance activities carried out by companies affect the assessment of investors from two perspectives. On the one hand, tax avoidance is considered positive because this activity can secure company resources used to serve investors (Kovermann, 2018). Tax avoidance activity is a company's efficient efforts to reduce its tax obligations. On the other hand, tax avoidance is considered risky because it creates tax disputes in the future, which will impact the company's after-tax cash flow. Based on agency theory, the agent can act opportunistically by utilizing asymmetric information to fulfill their interests through tax avoidance activities (Firmansyah and Triastie, 2020). Tax avoidance causes the company's accounting transparency to be poor and increases the uncertainty of future income that investors will obtain. Due to tax avoidance activities, poor accounting transparency increases the risk of information asymmetry that impairs capital market efficiency and uncertainty over investment returns (Shin and Woo, 2018).

Companies with a high level of asymmetric information will choose to finance through debt even though it increases their debt ratio (Yeh et al., 2020). In addition, companies that make tax savings to maximize firm value will increase the use of debt rather than equity in their funding structure (Firmansyah et al., 2020). It causes creditors to have better access to information than ordinary stockholders in assessing the company's ability. Common stockholders who have access to less information will increase the expected rate of return, thereby increasing the cost of equity. This higher rate of return reflects the risk borne by common stockholders who are not better informed than creditors (e.g., liquidation information) (Yeh et al., 2020).

On the other hand, the use of debt can increase the risk of default, affecting the company's credit rating. A decrease in the company's credit rating will increase the company's cost of debt (Jiraporn et al., 2014). (Chun et al., 2019) found that tax avoidance activities can increase a firm's cost of equity in countries with weak investor protection. Inadequate investor protection makes investors view tax avoidance activities as risky because it creates more agency conflicts and sets a higher equity risk premium. The equity risk premium is a component that adds to the company's cost of equity as described in the capital asset pricing model. Furthermore, (Febriyanto and Firmansyah, 2018) found that tax avoidance leads to investors bearing the risk of increasing investment uncertainty which causes an increase in the company's cost of equity. Therefore, tax avoidance can increase the cost of capital by increasing the cost of debt and equity.

H1: $_{1}$ Tax avoidance is positively associated with the cost of capital.

Companies have reasons to implement aggressive tax avoidance because it can generate benefits in higher after-tax corporate cash flows that increase shareholder value (Hutchens and Rego, 2017). On the other hand, aggressive tax avoidance results in higher uncertainty over future after-tax cash flows, which are riskier. Aggressive tax avoidance involves a unique activity that, in its implementation, requires high and complex costs to provide a low chance of success (Hutchens and Rego, 2017). Aggressive tax avoidance is a tax position that is more challenging to tax authorities. This position risks being audited by the taxation authority, resulting in higher tax payments from underpayment of taxes, interest, and penalties. Tax aggressiveness can reduce the transparency of financial statements 
because companies generally hide these activities, especially to tax authorities (Guenther et al., 2017). These activities can increase information asymmetry based on agency theory, which investors consider risky. Based on the theory, rational investors do not like risk (riskaverse) and demand a higher rate of return from risky companies. (Hutchens and Rego, 2017) found that more aggressive tax avoidance increases the implied cost of firm equity. Aggressive tax avoidance activities lead to uncertainty over the company's after-tax cash flows. The literature discusses the impact of tax aggressiveness on the cost of debt is very rare. Still, (Kubick and Lockhart, 2017) found that tax aggressiveness impacts the contract structure of corporate debt with shorter maturities. Investors set shorter debt maturities to avoid the risk of tax aggressiveness. Based on this perspective, investors and creditors view aggressive tax avoidance as a risky condition for the company, resulting in a high cost of capital.

H2: Tax aggressiveness is positively associated with the cost of capital.

The amount of tax risk depends on the tax position taken by the company. The more aggressive the company's tax position, the higher the exposure to corporate tax risk. Based on agency theory, tax aggressiveness will lead to asymmetric information where companies will cover up aggressive tax avoidance activities to avoid audit risk by tax authorities. According to (Guenther et al., 2017), tax avoidance can increase corporate risk because tax avoidance activities increase the uncertainty of future corporate tax payments by anticipating challenges with tax authorities or transactions resulting in tax savings. Tax is a burden that reduces the amount of pre-tax income by a large portion and is a material cost that is repeated so that the uncertainty of tax payments will significantly affect the after-tax cash flow (Hutchens and Rego, 2017). Thus, aggressive tax avoidance will result in tax risk as reflected in unpredictable after-tax cash flows. This condition is considered a risky matter by potential investors, which causes them to increase their expected rate of return as compensation for the risk of placing funds. (Kovermann, 2018) found that tax risk positively affects the cost of debt. Creditors assume companies that pay an unstable tax burden as riskier debtors and therefore charge a higher cost of debt. (Hutchens and Rego, 2017) found that tax risk has a positive effect on the cost of equity. High tax risk is described as high after-tax cash flow volatility, affecting the company's ability to distribute after-tax cash flows. Investors assume this condition as a risky matter, thereby increasing the company's cost of equity. Therefore, tax risk can increase the cost of capital by increasing the cost of debt and equity.

H3: Tax risk is positively associated with the cost of capital.

Based on stakeholder theory, tax avoidance is not an ethical activity because taxes are a form of corporate responsibility as citizens who enjoy public facilities provided by the government through funds derived from taxes (Firmansyah and Estutik, 2020). Thus, we need a mechanism that aligns the interests of the company and the demands of investors so that the company behaves ethically. Corporate social responsibility disclosure is one of the mechanisms to align the ethics of managers with the expectations of stakeholders (Agudelo et al., 2019). Social responsibility disclosure can be considered an effective mechanism for potential investors to make correct investment decisions and effectively lower the cost of 
capital. Tax avoidance causes the company's accounting transparency to be poor, increasing the risk of information asymmetry that distorts investors' decisions to invest in companies. Companies seek to reduce information asymmetry to reduce the company's cost of capital (Yeh et al., 2020). Thus, lower information asymmetry can lower the cost of capital. Disclosure of social responsibility can reduce the cost of capital by lowering asymmetric information (Suto and Takehara, 2017; Yeh et al., 2020). More responsible companies obtain a more favorable credit rating and improve access to finance in the capital market to get loans with low debt costs (Jiraporn et al., 2014). Corporate social responsibility disclosure reduces the asymmetric information companies face in obtaining external financing. Also, it can reduce tax avoidance activities because the public perspective these activities as unethical activities. Concerning the cost of capital, corporate social responsibility disclosure can reduce asymmetric information between management and investors, thereby increasing investors' ability to assess the company's fund placement decisions. Companies are not motivated to use more debt in their funding structure due to decreased asymmetric information. Theoritacally, a socially responsible company will obtain a lower cost of capital because it increases the credit rating in the eyes of creditors. Company managers will be aligned with investors' objectives as stakeholders in improving the firm value through an optimal funding structure.

H4: Corporate social responsibility disclosure weakens the positive effects of tax avoidance and the cost of capital.

Tax aggressiveness is a more challenging tax position that risks being audited by higher tax authorities (Lietz, 2013). Based on the second hypothesis, tax aggressiveness can reduce the transparency of financial statements because companies generally hide these activities from the public, especially tax authorities. Based on stakeholder theory, the company seeks to satisfy all parties affected by the company's actions or policies by behaving responsibly, one of which is related to corporate accountability. Corporate social responsibility provides a control mechanism so that companies comply with the principles of responsible behavior, thereby eliminating the opportunity for companies to hide aggressive tax avoidance (Whait et al., 2018). Furthermore, companies that frequently disclose tax information, not as a progressive form of social responsibility, aim to give the impression when pressured by stakeholders (Whait et al., 2018). Stakeholder stakeholders employ corporate social responsibility disclosure as evaluation material for company performance and are considered a practice of corporate accountability (Gunawan, 2017). Thus, the implementation of tax aggressiveness practices that tend to be hidden by companies can be suppressed through disclosure of social responsibility. In addition, aggressive tax avoidance is a global sustainability problem because it can erode common social and environmental resources (Whait et al., 2018). Companies that disclose social responsibility must carry out their operations by considering the balance of economic, social and environmental aspects. Companies are required to be more ethical and not ethical if company policies have a negative impact on the environment and social. The public demands that companies report their business activities more accountable. On the other hand, it can reduce asymmetric information between management and investors, thereby increasing investors' ability to assess its fund placement decisions. More effective 
communication due to lower information asymmetry further limits the potential for managerial opportunism and builds stakeholder trust (Pérez, 2015).

H5: Corporate social responsibility disclosure weakens the positive effect of tax avoidance and the cost of capital.

Tax risk is defined as the dispersion of the results of aggressive tax avoidance (Drake et al., 2019). (Guenther et al., 2017) described it as the uncertainty of paying taxes and penalties in the future related to the current tax position taken by the company. Tax aggressiveness creates uncertainty over the company's future after-tax cash flows (Hutchens and Rego, 2017). Tax risk can arise from the company's tax management activities independently of the company's risk as a whole. Due to aggressive tax avoidance activities, the low tax rate risks a spike in future tax payments, affecting the company's overall risk. Based on stakeholder theory, companies will be more responsible in their business policies if they carry out social responsibility by upholding the value of accountability. Thus, aggressive tax avoidance activities that generate high tax risk can be implemented more controlled and have implications for more stable corporate tax payments. The company will avoid the risk of underpayment of taxes, interest penalties and fines. This condition can reduce the perception of risk for investors by setting a lower expected return and has implications for the lower cost of capital.

H6: Corporate social responsibility disclosure weakens the positive effect of tax risk and cost of capital.

\section{METHODS}

This study employs secondary data from financial statement data, stock price information, and 10-year government bond yields. The data was obtained from the websites www.idx.co.id, www.idnfinancials.com, www.finance.yahoo.com, and www.bloomberg.com. The sample selection process using purposive sampling method in this study with the following criteria:

Table 1. Research Sample

\begin{tabular}{lc}
\hline Criteria & Number \\
\hline Manufacturing sector companies listed on the IDX as of May 2021 & 137 \\
Companies listed on the IDX after January 1, 2012 & -12 \\
Incomplete elements and/or information of financial statements & -15 \\
Companies that have interest expenses but do not have information on debt that bears interest & -4 \\
Companies that have negative cumulative pretax income from 2016 to 2020 & -41 \\
Number of companies used & 65 \\
Number of Years & 5 \\
Total Sampel (Firm Year) & 325 \\
\hline
\end{tabular}

Source: Processed

The dependent variable in this study is the cost of capital. There are two types of capital costs used in this study: equity and debt. The cost of capital is proxied by the Weighted Average Cost of Capital (WACC) by first calculating the company's cost of equity 
and debt. The cost of equity was estimated using the Capital Asset Pricing Model (CAPM) as used by (Febrininta and Siregar, 2014), (Firmansyah et al., 2021), (Kling et al., 2021), and (Nuryatno et al., 2019). The CAPM equates the firm's cost of equity with the risk-free interest rate plus the firm's beta times the market risk premium.

$\mathrm{COE}_{\mathrm{it}}=\mathrm{R}_{\mathrm{f}}+\beta\left(\mathrm{R}_{\mathrm{m}}-\mathrm{R}_{\mathrm{f}}\right)$

Where:

$\mathrm{COE}=$ cost of equity of firm $\mathrm{i}$ in year $\mathrm{t}$

Rf $\quad=$ risk-free rate with 10-year government bonds yield

$\beta \quad=$ beta value/systematic risk of the company, resulting from the regression between the IDX composite on individual stock returns.

$\mathrm{R}_{\mathrm{m}} \quad=$ market rate of return calculated based on IDX composite returns

Furthermore, the measurement of the cost of debt in this study follows (Kovermann, 2018), (Yeh et al., 2020), and (Firmansyah et al., 2021). The cost of debt is estimated by the ratio of the interest expense paid by the company in one year divided by the average number of loans that earn interest.

$\mathrm{COD}_{\text {it }}=\frac{\text { Interest Expenses }_{\text {it }}}{\text { Average Interest-Bearing Debt }}$ it

Where:

$\mathrm{COD}_{\mathrm{it}} \quad=$ cost of debt of company $\mathrm{i}$ in year $\mathrm{t}$

Interest Expense $_{i t} \quad=$ interest expense of company $\mathrm{i}$ in year $\mathrm{t}$

Average Interest Bearing Debt ${ }_{i t}=$ average interest-bearing debt of company $i$ in year $t$

The last step is to calculate the cost of capital using the Weighted Average Cost of Capital (WACC) model as employed by (Suto and Takehara, 2017) and (Firmansyah et al., 2021). WACC is a weighted average of all components of the company's owned capital. However, in this study, the WACC calculation only uses the company's capital from equity and debt. WACC is calculated on the cost of debt after calculating the company's marginal tax rate to determine the effect of the debt tax shield.

WACC $_{\text {it }}=\frac{\text { Equity }_{\text {it }}}{\text { Equity }_{i t}+\text { Debt }_{i t}} * \operatorname{COE}+\frac{\text { Debt }_{i t}}{\text { Equity }_{i t}+\text { Debt }_{i t}} * \operatorname{COD}(1-\mathrm{T})$

Where:

$\mathrm{WACC}_{\mathrm{it}} \quad=$ cost of capital of company $\mathrm{i}$ in year $\mathrm{t}$

Equity $_{\text {it }} \quad=$ total equity of company $i$ in year $t$

Debt $_{i t} \quad=$ amount of interest-bearing debt of company $\mathrm{i}$ in year $\mathrm{t}$

$\mathrm{COE}_{\mathrm{it}} \quad=$ cost of equity of company $\mathrm{i}$ in year $\mathrm{t}$ (equation 1 )

$\mathrm{COD}_{\mathrm{it}} \quad=$ cost of debt of company $\mathrm{i}$ in year $\mathrm{t}$ (equation 2 )

$\mathrm{T}=$ firm $\mathrm{i}$ 's marginal tax rate in year $\mathrm{t}$ (1-marginal tax rate)

The independent variables in this study are tax avoidance, tax aggressiveness, and tax risk. The proxy for tax avoidance in this study uses the cash effective tax rate (ETR) as (Guenther et al., 2017) and (Wardani et al., 2019), which is calculated cumulatively for 5 years, namely from the current year $(\mathrm{t})$ to the previous 4 years $(\mathrm{t}-4)$, as follows: 
CETR $_{\text {it }}=\frac{\sum_{\mathrm{t}=1}^{\mathrm{n}} \text { Cash Tax Paid }}{\mathrm{it}}$

Where:

CETR $_{\text {it }}$

Cash Tax Paid

$=$ Cash ETR of the company $i$ in year $t$ measured for 5 years

Pretax Income

$=$ Cash payment of corporate tax $\mathrm{i}$ in year $\mathrm{t}$ measured for 5 years

$=$ Earnings before tax of company $i$ in year $t$ measured for 5 years

A low CETR value indicates a high level of tax avoidance (Ferdiawan and Firmansyah, 2017; Firmansyah and Muliana, 2018). This study employs discretionary permanent book-tax difference (DTAX) as a proxy to measure tax aggressiveness, follows (Firmansyah and Estutik, 2020), (Guenther et al., 2017), (Hutchens and Rego, 2017), Rachmawati and Martani, 2017) by adjusting accounting standards and tax regulations in Indonesia based on (Rachmawati and Martani, 2017), as follows:

PERMDIFF $=\alpha+\alpha_{1}$ INTANG $_{i t}+\alpha_{2}$ NOL $_{i t}+\alpha_{3}$ LAGPERM $_{i t}+\varepsilon_{i t}$

Where:

PERMDIFF $_{\text {it }}=$ Total book-tax differences minus temporary book-tax differences for the company $\mathrm{i}$ in year $\mathrm{t}$. (book earnings before tax-tax expense/tax rate)(deferred tax expense/tax rate)

INTANG $_{\text {it }} \quad$ Goodwill and other intangible assets of the company $\mathrm{i}$ in year $\mathrm{t}$

$\triangle \mathrm{NOL}_{\mathrm{it}} \quad=$ Change in net operating loss carryforwards of the company $\mathrm{i}$ in year $\mathrm{t}$

LAGPERM $_{\text {it }} \quad=$ PERMDIFF of company i's previous year in year $\mathrm{t}$

$\varepsilon_{\mathrm{it}} \quad=$ discretionary permanent book-tax different company $\mathrm{i}$ in year $\mathrm{t}$

The proxy of tax risk in this study employs CETR volatility follows (Guenther et al., 2017) as the standard deviation of the CETR calculated for 5 years, namely from the current year $(\mathrm{t})$ to the previous 4 years $(\mathrm{t}-4)$, as follows:

CETR Volatility $=\operatorname{STDEV}\left(\right.$ CETR $_{\text {it }-4}+$ CETR $_{\text {it }-3}+$ CETR $_{\text {it }-2}+$ CETR $_{\text {it }-1}+$ CETR $\left._{\text {it }}\right)$

Where:

CETR Volatility = standard deviation of firm i's cash ETR for 5 years

STDEV = standard deviation

CETR $\quad=$ cash ETR of company $\mathrm{i}$ in year $\mathrm{t}$

This study includes a moderating variable in social responsibility disclosure with a CSR Disclosure Index (CSRI) proxy based on the Global Reporting Initiative (GRI) standard. The GRI standard has 77 indicators which are divided into three categories, namely the economic category (13 indicators), the environmental category (34 indicators), and the social category (30 indicators). This study employs a scale to calculate the score for each object of disclosure in the annual report and/or company sustainability report, according to (Firmansyah and Estutik, 2020). 
Table 2. Corporate Social Responsibility Disclosure Index

\begin{tabular}{cl}
\hline Scale & \\
\hline 0 & No disclosure \\
1 & Minimum disclosure or brief disclosure \\
2 & Descriptive: Presents a definite impact on the company or policy \\
3 & Quantitative: Impact on the company is clearly defined in terms of the monetary or physical quantity \\
4 & Extraordinary disclosure
\end{tabular}

Source: Processed

After the corporate social responsibility disclosure score is obtained, it is then added and calculated with the following calculations:

CSRIit $=\frac{\sum \mathrm{X}_{\mathrm{it}}}{\sum \mathrm{n}_{\mathrm{it}}}$

Where:

CSRit = CSR Disclosure Index of the company $\mathrm{i}$ in year $\mathrm{t}$

$\Sigma$ Xit $\quad=$ Number of CSR indicators disclosed by the company

$\Sigma$ nit $\quad=$ Number of disclosure criteria based on GRI standards

This study includes three control variables, namely leverage, firm size and profitability, which are confirmed to have a significant effect on the cost of capital, both the cost of debt and the cost of equity (Febriyanto and Firmansyah, 2018; Goh et al., 2016; Kovermann, 2018; Shin and Woo, 2018). Based on (Kovermann, 2018), leverage is calculated as long-term debt plus short-term debt divided by total assets.

$$
\text { LEV }=\frac{\text { Total Liabilities }}{\text { Total Assets }}
$$

Company size describes the size of the company as measured by total assets. Firm size is calculated as the natural logarithm of total assets.

$$
\text { Size }=\log (\text { Total Aset })
$$

Furthermore, profitability describes the company's ability to generate profits by using all assets owned by the company. Profitability is calculated by the return on assets (ROA) ratio, namely profit before tax divided by total assets.

$$
\text { ROA }=\frac{\text { Earnings Before Tax }}{\text { Total Assets }}
$$

To determine the effect of the independent variable on the dependent variable, this study used a panel data regression model. There are two models in this study. The first model is used to examine the effect of tax avoidance, tax aggressiveness and tax risk on the cost of capital as presented in the first hypothesis to the third hypothesis, which is as follows:

COC $_{\text {it }}=\beta_{0}+\beta_{1}$ CETR $_{i t}+\beta_{2}$ DTAX $_{i t}+\beta_{3}$ CETR_Vol $_{\text {it }}+\beta_{4}$ LEV $_{i t}+\beta_{5}$ SIZE $_{i t}+\beta_{6}$ ROA $_{i t}+$

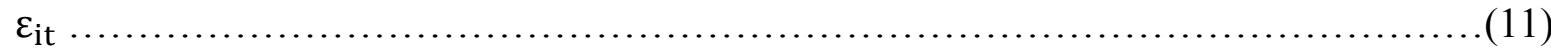


Furthermore, to examine the role of disclosure of social responsibility in moderating the effect of the independent variable on the dependent variable as stated in the fourth to sixth hypotheses, model two is used as follows:

$$
\begin{aligned}
& \mathrm{COC}_{\text {it }}=\beta_{0}+\beta_{1} \text { CETR }_{\text {it }}+\beta_{2} \text { DTAX }_{\text {it }}+\beta_{3} \text { CETR_Vol }_{\text {it }}+\beta_{4} \text { LEV }_{\text {it }}+\beta_{5} \text { SIZE }_{\text {it }}+
\end{aligned}
$$

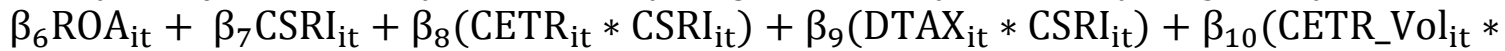

$$
\begin{aligned}
& \left.\mathrm{CSRI}_{\mathrm{it}}\right)+\varepsilon_{\mathrm{it}} \\
& \text { Where: } \\
& \mathrm{COC}_{\mathrm{it}} \quad=\text { company's cost of capital } \\
& \text { CETR }_{\text {it }}=\text { corporate tax evasion using the Cash ETR. } \\
& \text { DTAX }_{\mathrm{it}}=\text { corporate tax aggressiveness using proxy discretionary permanent book- } \\
& \text { tax different } \\
& \text { CETR_Vol }{ }_{i t}=\text { corporate tax risk using the Cash ETR Vol Volatility proxy } \\
& \mathrm{LEV}_{\text {it }} \quad=\text { company leverage } \\
& \text { SIZE }_{i t} \quad=\text { company size } \\
& \text { ROA }_{\text {it }} \quad=\text { company profitability } \\
& \text { CSRI }_{\mathrm{it}} \quad=\text { corporate social responsibility disclosure it }
\end{aligned}
$$

\begin{tabular}{|c|c|c|c|c|c|c|c|c|c|}
\hline \multirow[t]{2}{*}{ Var } & \multirow[t]{2}{*}{ Sign } & \multicolumn{4}{|c|}{ Model 1} & \multicolumn{4}{|c|}{ Model 2} \\
\hline & & Coeff & t-Stat & Prob & & Coeff. & t-Stat & Prob & \\
\hline $\mathrm{C}$ & & 0.166 & 1.308 & 0.0959 & $*$ & 0.026 & 0.162 & 0.871 & \\
\hline CETR & - & 0.0009 & 0.169 & 0.4328 & & -0.0222 & -1.191 & 0.1173 & \\
\hline DTAX & + & 0.090 & 0.672 & 0.2508 & & -0.179 & -0.562 & 0.2871 & \\
\hline CETR_VOL & + & -0.001 & -2.401 & 0.0084 & $* * *$ & 0.011 & 1.170 & 0.1213 & \\
\hline LEV & & -0.086 & -3.212 & 0.0008 & $* * *$ & -0.0888 & -3.296 & 0.0005 & $* * *$ \\
\hline
\end{tabular}

\section{RESULTS}

The summary of the results of descriptive statistics in this study is presented in Table 3 .

Table 3. Descriptive Statistics

\begin{tabular}{llccccc}
\hline Var. & Obs & Mean & Med & Std. Dev. & Min. & Max \\
\hline COC & 325 & 0.0575 & 0.053 & 0.1371 & -0.641 & 0.818 \\
CETR & 325 & 0.4801 & 0.263 & 1.4344 & 0.024 & 23.316 \\
DTAX & 325 & 0.0013 & -0.002 & 0.0613 & -0.49 & 0.688 \\
CETR_VOL & 325 & 2.2428 & 0.151 & 14.448 & 0.009 & 131.351 \\
CSRI & 325 & 0.4870 & 0.364 & 0.3882 & 0.078 & 2.623 \\
LEV & 325 & 0.4362 & 0.386 & 0.2844 & 0.092 & 2.9 \\
SIZE & 325 & 28.809 & 28.598 & 1.7591 & 25.216 & 33.495 \\
ROA & 325 & 0.0701 & 0.055 & 0.0922 & -0.600 & 0.607 \\
\hline
\end{tabular}

Source: Processed

Furthermore, based on the results of the Chow test, Lagrange multiplier test, and Hausman test, the fittest model in equations 1 and 2 is the random effect model. The summary of the results of the hypothesis test is as follows:

Table 4. The Summary of Hypothesis Tests 


\begin{tabular}{clllllll} 
SIZE & -0.002 & -0.554 & 0.2899 & 0.0031 & 0.542 & 0.2939 & \\
ROA & 0.027 & 0.293 & 0.3849 & 0.0102 & 0.111 & 0.4560 & \\
CSRI & & & & -0.0606 & -1.681 & 0.0469 & $* *$ \\
CETR*CSRI & & & & 0.1151 & 1.0751 & 0.1415 & \\
DTAX*CSRI & & & & 0.6735 & 0.985 & 0.1626 & \\
CETR_VOL*CSRI & & & & -0.0355 & -1.347 & 0.0895 & $*$ \\
R $^{2}$ & & 0.0507 & & & & 0.0678 & \\
Adj. R $^{2}$ & & 0.0328 & & & & 0.0381 & \\
F-Stat. & 2.8313 & & & & 2.2842 & \\
Prob. (F-Stat.) & 0.0106 & & & & & 0.0135 \\
\hline
\end{tabular}

Source: Processed

\section{DISCUSSIONS}

The association between tax avoidance and cost of capital. The test result suggests that tax avoidance is not associated with cost of capital. This result is not in line with the research conducted by (Shin and Woo, 2018), which found that tax avoidance is seen as a negative signal from creditors' perspective. This result is not in line with (Febriyanto and Firmansyah, 2018), who found that tax avoidance activities improve the cost of equity. The difference in the results of this study is due to differences in the use of the dependent variable, which in this study uses the cost of capital as a proxy for the Weighted Average Cost of Capital (WACC), which is a weighted average of the cost of debt and equity. In contrast, previous studies used a partial proxy of cost of capital, cost of equity, and cost of debt. This result confirms that the tax avoidance activities carried out by companies affect investors' assessments from two points of view. Besides being seen as a risky thing, tax avoidance is considered positive activity because this activity can secure company resources used to serve investors (Kovermann, 2018). Tax avoidance is viewed as a company's efficient efforts to reduce its tax obligations, increasing its ability to pay debts to creditors.

According to (Yeh et al., 2020), countries in the emerging market category use debt more than equity. The Bank views tax avoidance activity as a non-risky thing. It pays more attention to other factors in the risk analysis process, such as its ability to generate cash flow. In addition, (Goh et al., 2016) found that tax avoidance activities have a negative effect on the cost of equity because tax avoidance activities have a positive cash flow effect on the company. An increase in positive cash flow will increase the number of dividends distributed to investors. Based on agency theory, agents can act opportunistically by utilizing information asymmetry to fulfill their interests through tax avoidance activities. Tax avoidance activities will increase firm value (Irawan and Turwanto, 2020; Widodo and Firmansyah, 2021). The use of debt will create tax protection in the form of a tax shield where interest payments are a deductible component of taxable income. However, this condition arises when debt in the company's capital structure is optimal. Agency problems arise when the company uses debt beyond the optimal point, which increases the company's risk.

The use of debt by the company is still at the optimal point. Tax avoidance activities carried out by companies increase the effect of the tax shield, which can be responded to positively by the market. Investors are assumed to be more focused on the results of corporate tax avoidance activities, in the form of increasing resources resulting from a decrease in taxable income due to the effect of tax shields, than the tax avoidance activity 
itself. Tax avoidance is not always responded negatively by investors by increasing the expected rate of return, which impacts the higher cost of capital.

The association between tax aggressiveness and cost of capital. The test result suggests that tax aggressiveness is not associated with cost of capital. This result is not in line with (Hutchens and Rego, 2017), which found that tax aggressiveness will increase cost of equity. The difference in the results of this study is due to differences in the use of tax aggressiveness proxies. (Hutchens and Rego, 2017) employed several tax aggressiveness proxies, including DTAX and Tax Reserves. (Hutchens and Rego, 2017) confirmed DTAX as a measure of aggressive tax avoidance activity that cannot capture risk significantly. This result was further confirmed by research conducted by (Guenther et al., 2013), which found that the Uncertained Tax Benefit (UTB) Reserves variable is a tax aggressiveness measure that can capture risk if there is high uncertainty regarding future tax payments. Managers attempt to carry out tax aggressiveness by utilizing information asymmetry to produce low transparency based on agency theory. Aggressive tax avoidance involves a unique activity and in its implementation requires high costs and complex implementation results in decreased information transparency. However, tax aggressiveness provides a low chance of success (Hutchens and Rego, 2017). These conditions make managers reconsider carrying out aggressive tax avoidance activities. This impacts corporate tax payments that do not experience a significant spike, in the sense that the company can maintain its effective tax rate continuously.

Furthermore, complex tax avoidance is difficult for tax authorities to detect, especially since managers deliberately hide this activity. For example, when a company invests in a country with a lower tax rate jurisdiction, it can have persistent implications for its tax rate. Tax management will increase the company's risk if the activity increases the uncertainty of the company's tax payments in the future (Guenther et al., 2013). Tax aggressiveness is difficult to detect, and its implementation does not result in significant tax payment volatility. Thus, it does not fully impact the company's risk, so it does not affect investors' assessment of the expected rate of return.

The association between tax risk on cost of capital. The test result suggests that tax risk is negatively associated with cost of capital. This result is different from (Hutchens and Rego, 2017) and (Kovermann, 2018). The difference in the test results is caused by the difference in the proxies used in the study. (Hutchens and Rego, 2017) employed Tax Reserves as a proxy for tax risk, while (Kovermann, 2018) uses Delta Inv, the standard deviation of Delta, as a proxy for tax avoidance in the research. Meanwhile, this study employs the standard deviation of Cash ETR as a proxy for tax risk. Another reason is that companies with low tax rates tend to have low tax risk. A low tax rate tends to be more persistent than a high tax rate. It shows that companies that are successful in tax avoidance tend to maintain that position for a long time (Guenther et al., 2013). (Hutchens and Rego, 2017) and (Kovermann, 2018) employed company data in developed countries with a longer research period. Differences in the use of data can cause different risks, both from internal and external to the company. (Firmansyah and Muliana, 2018) explained that external factors are more dominant in the uncertainty of tax payments for companies located in Indonesia. Economic conditions, politics and attacks from foreign products impact government decisions in setting tax policies. The company only responds to government 
policies in carrying out its tax obligations. Thus, tax risk in Indonesia as a developing country is more influenced by external factors than internal company factors. Tax risk as one of the components that make up the company's risk is responded positively by investors due to the factors that cause tax risk.

This study defines tax risk as to the uncertainty of tax payments caused by the company's tax position (company tax management activities). However, external factors are more dominant in anticipation of tax payments for companies located in Indonesia (Firmansyah and Muliana, 2018). Tax risk is all tax-related uncertainties covering company operations, investments, funding decisions, audit risk and uncertainty in financial accounting (Hutchens and Rego, 2017). In addition, the determinants of corporate risk are not only derived from tax risk. (Oral and Akkaya, 2015) found that the uncertainty of a company's cash flows can affect its risk, which impacts investor response and choice in determining its funding source. Deviant cash flows will increase the volatility of cash flows, which impacts company risk (e.g., financial distress). This condition will affect the company in determining its capital structure based on the risk response of investors in determining the expected rate of return.

The role of corporate social responsibility disclosure on the association between tax avoidance and cost of capital. The test result suggests that corporate social responsibility disclosure does not weaken the positive effect of tax avoidance on the cost of capital. Corporate social responsibility is a way for companies to consider environmental, social and governance factors in corporate decisions and business while maintaining relationships with stakeholders (Yeh et al., 2020). In general, corporate social responsibility is defined as a continuous commitment in the business world to be economically, socially, and ecologically responsible for preventing negative impacts and improving the quality of the surrounding community and the environment that are company stakeholders (Pradipta and Supriyadi, 2015). According to stakeholder theory, the company's responsibility is not limited to the welfare of the owner of the company. The company has social responsibility by considering the interests of all parties affected by the company's actions or policies (Pradipta and Supriyadi, 2015). Companies must behave ethically and responsibly in carrying out their operational activities to all affected parties. However, the results of this study do not succeed in confirming the stakeholder theory, where socially responsible companies will avoid unethical behavior such as reducing their tax payments because the tax burden is a burden that does not come from the results of business transactions similar to the company's operating costs (Firmansyah and Estutik, 2020). Tax is one of the sources of state income used to provide public facilities for the wider community. Thus, according to stakeholder theory, the people affected by the payment of corporate taxes are a group of stakeholders. Companies that are socially responsible and ethical will pay taxes fairly, following tax regulations. This condition shows corporate social responsibility as a control tool. The company fulfills the principles of responsible and ethical behavior to eliminate the company's opportunity to do tax avoidance.

Corporate social responsibility disclosure does not have a role in the association between tax avoidance and cost of capital is caused by several things. The first reason is the lack of awareness of companies in Indonesia on social responsibility activities. It can be seen from the mean value of social responsibility disclosure which is still low, namely 0.486873 or only $12.25 \%$ of the maximum score of the disclosure. The disclosure in 
Indonesia has only become an obligation to fulfill the demands of the bureaucracy without paying attention to the quality of the activity.

Corporate social responsibility disclosure is required for public companies in Indonesia based on the Financial Services Authority regulation No. 29/POJK.04/2016, and the criteria that must be disclosed are regulated in Bapepam-LK decree No. 431/BL/2012. However, disclosures made by the company are only one-sided claims of the company and are voluntary. The criteria that must be disclosed in the regulation only focus on environmental aspects, so it does not meet the overall sustainability aspect. In addition, the obligation to disclose social responsibility is not regulated in financial accounting standards. This condition shows that the quality of social responsibility disclosure activities in Indonesia has not been maximally carried out. The function of social responsibility as a tool to reduce information asymmetry has not been achieved. This fact causes managers to remain free to carry out opportunistic activities, one of which is tax avoidance.

The role of corporate social responsibility disclosure in the association between tax aggressiveness and cost of capital. The test result suggests that corporate social responsibility disclosure does not weaken the positive effect of tax aggressiveness on the cost of capital. Aggressive tax avoidance poses the risk of being audited by the tax authorities, which results in higher future tax payments from underpayment of taxes, interest and penalties. Companies are attempting to cover up this activity, which impacts the transparency of financial statements that are getting worse. Companies hide these activities, especially to the public, especially the tax authorities (Guenther et al., 2017). Furthermore, (Whait et al., 2018) stated that corporate social responsibility could provide a control mechanism so that companies comply with the principles of responsible behavior, thereby eliminating the opportunity for companies to hide aggressive tax avoidance. The results showed that the disclosure of social responsibility could not weaken the relationship between tax aggressiveness and the cost of capital. Thus, this study failed to confirm the stakeholder theory, which states that companies will avoid unethical behavior to meet stakeholder demands. Tax aggressiveness is an unethical activity because it affects corporate accountability because the quality of corporate social responsibility disclosure activities in Indonesia which has not been maximized. This is confirmed by the mean value of the scoring of the corporate social responsibility disclosure of manufacturing companies in Indonesia from 2016 up to 2020 , which only reached $12.25 \%$. This fact impacts the weak function of social responsibility as a tool to control the company's behavior to fulfill responsible principles. In addition, the obligation to disclose social responsibility is not regulated in financial accounting standards. Tax aggressiveness is carried out by obscuring corporate accountability, which impacts the quality of the information in financial statements. It discloses social responsibility as a component that is not relevant to the quality of information on the company's financial statements.

(Laguir et al., 2015) stated that corporate tax aggressive avoidance depends on which dimension of social responsibility is dominantly carried out by the company. The social dimension can limit the company's aggressive tax avoidance activities (Laguir et al., 2015). Companies with social responsibility that are more dominant in the economic and environmental dimensions tend to have a high tax aggressiveness. Thus, companies involved in socially responsible human resources, human rights and community involvement are less likely to engage in tax aggressiveness. It confirms that the corporate social responsibility 
disclosure in Indonesia has not succeeded in influencing the activities of corporate tax aggressiveness because the environmental dimension still dominates the disclosure. Also, the quality of the implementation of social responsibility in Indonesia is still not optimal, which causes the ideal conditions for social responsibility as a tool to control corporate behavior to fulfill responsible principles have not been successfully implemented.

The role of corporate social responsibility disclosure in the association between tax risk and cost of capital. The test result suggests that corporate social responsibility disclosure weakens the positive effect of tax risk on the cost of capital. (Hutchens and Rego, 2017) and (Kovermann, 2018) found that tax risk positively affects cost of capital. At the same time, (Yeh et al., 2020) concluded that high social responsibility performance could lower the company's cost of debt. Based on these findings, corporate social responsibility disclosure can weaken the positive effect of tax risk on the cost of capital. However, the quality of the corporate social responsibility disclosure in Indonesia is not optimal, confirmed by the mean value of the disclosure of social responsibility of manufacturing companies in Indonesia during 2016 s.d. 2020, which only reached $12.25 \%$. (Hamilton and Stekelberg, 2017) stated that companies with good information technology could enjoy tax savings and lower tax risk than companies with less advanced information technology. CSR disclosure can lower tax risk (Lin et al., 2019). However, companies with good performance can only enjoy the benefits of disclosing social responsibility. The benefits of disclosing social responsibility against tax risk will be lost in companies with low levels of profitability. Managers in companies with low levels of profitability and who continue to carry out social responsibility activities will look for other resources, one of which is through aggressive tax savings. This result succeeds in confirming that companies will avoid unethical behavior such as making aggressive savings. Managers who are faced with limited resources will make aggressive tax savings to continue carrying out social responsibility activities. In addition, tax risk factors are not only based on tax management activities. Other activities are still within the ethical criteria that companies can do in making tax savings.

Furthermore, (Laguir et al., 2015) stated that companies that dominantly disclose economic and environmental dimensions in their social responsibility disclosures tend to do aggressive tax avoidance. The economic dimension relates to the quality of the product or service provided by the company. The impact of this dimension is limited only to customers, suppliers and investors. At the same time, the positive effect of social responsibility can only arise when its impact impacts the wider environment (society). Managers carry out this dimension to achieve a higher level of profitability. Managers who focus on the level of profitability tend not to behave ethically (Lin et al., 2019). The quality of the implementation of social responsibility in Indonesia is still dominated by environmental aspects, causing the positive influence of corporate social responsibility not to be fully felt by the wider environment. In addition, the low level of profitability of manufacturing companies in Indonesia has resulted in managers not fully focusing on managing the company's risk from tax risk.

Although the current implementation of corporate social responsibility is still relatively low, future stakeholders' demands will naturally result in better performance. Implementation of corporate social responsibility has a positive impact on the company's long term. Aggressive tax avoidance activities that generate high tax risk can be more controlled and have implications for more stable corporate tax payments. The 
implementation of CSR for the long term avoids the company from the risk of underpayment of taxes, interest penalties and fines. This condition can reduce the perception of risk for investors by setting a lower expected return and implying a lower cost of capital.

\section{CONCLUSION}

Investors and creditors do not consider that tax avoidance activity as risky. Companies that conduct tax avoidance prefer to use debt in their funding structure rather than equity to benefit from the tax shield. Tax aggressiveness provides a low chance of success. These conditions make managers reconsider carrying out aggressive tax avoidance activities. Factors forming tax risk do not only come from corporate tax management activities. The company's external factors play a more dominant role in the uncertainty of tax payments for companies located in Indonesia, such as economic conditions, politics and attacks from foreign products that impact government decisions in setting tax policies. Furthermore, corporate social responsibility disclosure in Indonesia is still not optimal in quality. Applying the common law system in Indonesia causes the ethical factor in running a business not to become an important component. It does not succeed in minimizing tax avoidance and tax aggressiveness, which is a risky act. However, the implementation of corporate social responsibility has a positive impact on the company's long-term control of tax risk, leading to the company having more stable corporate tax payments.

This research has several limitations. The use of balanced data panels with purposive sampling technique causes many companies that do not meet the criteria to be eliminated in this study. Thus, of the 137 manufacturing companies listed on the Indonesia Stock Exchange from 2012 to 2020 , only 65 companies have met the purposive sampling criteria. This research involves determining the index score based on the annual report on the variable of social responsibility disclosure. The index score is determined independently without any other party confirming the index results. Future research can use all companies listed on the Indonesia Stock Exchange or other sectors other than the manufacturing sector and use the longer time horizon to obtain the comprehensive result.

Companies should be careful in determining the proportion of the use of debt to avoid the risk of financial distress, and the benefits of the tax shield can be enjoyed more. Companies need to increase awareness of the importance of social responsibility activities and disclose these activities to shape the ethical views of stakeholders towards the company and affect the perception of risk from investors. Creditors must be more aware of the company's risky activities. The decision to grant credit or loans to the company must still pay attention to the company's level of use of debt so that the use of debt remains at the optimal point. Furthermore, investors need to consider non-financial information, such as disclosure of social responsibility, in every decision to place their funds. It is intended so that investors can further mitigate risk and develop company choices as investment objects.

This study suggests that The Indonesia Financial Services Authority needs to standardize social responsibility disclosure items, especially developing social dimensions related to human resources, human rights and community involvement. Furthermore, the Indonesian Tax Authority should consider the addition of the manufacturing sector as a taxpayer that is exempt from the Debt to Equity Ratio provisions according to the current regulations. Also, the Authority needs to pay attention to the costs incurred by companies in carrying out social responsibility activities. 


\section{REFERENCES}

Agudelo, M. A. L., Jóhannsdóttir, L., and Davídsdóttir, B. (2019). A literature review of the history and evolution of corporate social responsibility. International Journal of Corporate Social Responsibility, 4(1), 1-23. https://doi.org/10.1186/s40991-018-0039.

AlHares, A. (2020). Corporate governance and cost of capital in OECD countries. International Journal of Accounting and Information Management, 28(1), 1-21. https://doi.org/10.1108/IJAIM-02-2019-0023.

Atmaja, S. (2020). Pengaruh manajemen laba terhadap biaya modal ekuitas melalui pengungkapan corporate social and environmental responsibility sebagai variabel intervening. Jurnal Manajemen Dan Bisnis, 2(1), 2027-2041. https://doi.org/10.47080/10.47080/vol1no02/jumanis.

Brigham, E. F., and Houston, J. F. (2019). Fundamentals of Financial Management. Cengage Learning.

Chun, H. M., Kang, G. I., Lee, S. H., and Yoo, Y. K. (2019). Corporate tax avoidance and cost of equity capital: international evidence. Applied Economics, 1-15. https://doi.org/10.1080/00036846.2019.1706716.

Deegan, C. (2014). Financial accounting theory. McGraw-Hill Education (Australia) Pty Ltd.

Drake, K. D., Lusch, S. J., and Stekelberg, J. (2019). Does tax risk affect investor valuation of tax avoidance? Journal of Accounting, Auditing and Finance, 34(1), 151-176. https://doi.org/10.1177/0148558X17692674.

Dyreng, S. D., Hanlon, M., and Maydew, E. L. (2008). Long-run corporate tax avoidance. Accounting Review, 83(1), 61-82. https://doi.org/10.2308/accr.2008.83.1.61.

Febrininta, C. N., \& Siregar, S. V. (2014). Manajemen laba akrual, manajemen laba riil, dan biaya modal. Jurnal Akuntansi Multiparadigma, 5(3), 365-379. https://doi.org/10.18202/jamal.2014.12.5027.

Febriyanto, A. S., and Firmansyah, A. (2018). The effects of tax avoidance, accrual earnings management, real earnings management, and capital intensity on the cost of equity. Jurnal Dinamika Akuntansi, 10(1), 40-50. https://doi.org/10.15294/jda.v10i1.12976.

Ferdiawan, Y., and Firmansyah, A. (2017). Pengaruh political connection, foreign activity, dan, real earnings management ter-hadap tax avoidance. Jurnal Riset Akuntansi Dan Keuangan, 5(3), 1601-1624. https://doi.org/10.17509/jrak.v5i3.9223.

Firmansyah, A., Andriani, A. F., dan Mahrus, M. L. (2021). Biaya modal perusahaan di Indonesia: tanggung jawab sosial dan tata kelola perusahaan. Jurnal Ekonomi, 26(3), 361-378. https://doi.org/10.24912/je.v26i3.796.

Firmansyah, A., and Estutik, R. S. (2020). Environmental responsibility performance, corporate social responsibility disclosure, tax aggressiveness: Does corporate governance have a role? Journal of Governance and Regulation, 9(4), 8-24. https://doi.org/10.22495/jgrv9i4art1.

Firmansyah, A., and Muliana, R. (2018). The effect of tax avoidance and tax Risk on corporate risk. Jurnal Keuangan Dan Perbankan, 22(4), 643-656. https://doi.org/10.26905/jkdp.v22i4.2237.

Firmansyah, A., and Purnama, E. B. D. (2020). Do derivatives instruments ownership decrease firm value in Indonesia? Riset Akuntansi Dan Keuangan Indonesia, 5(1), 19. https://doi.org/10.23917/reaksi.v5i1.9817.

Firmansyah, A., Setiawan, T. A., dan Fathurahman, F. (2020). Nilai perusahaan: kebijakan 
utang, good corporate governance, cash holding. Jurnal Akuntansi Dan Bisnis, 20(2), 237. https://doi.org/10.20961/jab.v20i2.568.

Firmansyah, A., and Triastie, G. A. (2020). The role of corporate governance in emerging market: Tax avoidance, corporate social responsibility disclosures, risk disclosures, and investment efficiency. Journal of Governance and Regulation, 9(3), 8-26. https://doi.org/10.22495/jgrv9i3art1.

Goh, B. W., Lee, J., Lim, C. Y., and Shevlin, T. (2016). The effect of corporate tax avoidance on the cost of equity. The Accounting Review, 91(6), 1647-1670. https://doi.org/10.2308/accr-51432.

Guenther, D. A., Matsunaga, S. R., \& Williams, B. M. (2013). Tax Avoidance, Tax Aggressiveness, Tax Risk and Firm Risk David A. Guenther, Steven R. Matsunaga*, Brian M. Williams Lundquist College of Business, University of Oregon, Eugene, OR 97403 USA August 2013. August.

Guenther, D. A., Matsunaga, S. R., \& Williams, B. M. (2017). Is tax avoidance related to firm risk? Accounting Review, 92(1), 115-136. https://doi.org/10.2308/accr-51408.

Gunawan, J. (2017). Pengaruh corporate social responsibility dan corporate governance terhadap agresivitas pajak. Jurnal Akuntansi, 21(3), 425-436. https://doi.org/10.24912/JA.V2113.246.

Hamilton, R., \& Stekelberg, J. (2017). The effect of high-quality information technology on corporate tax avoidance and tax risk. Journal of Information Systems, 31(2), 83-106. https://doi.org/10.2308/isys-51482.

Hutchens, M., \& Rego, S. (2017). Tax risk and cost of equity capital. Journal of Chemical Information and Modeling, 53(9), 1689-1699.

Indriyani, E. (2017). Pengaruh ukuran perusahaan dan profitabilitas terhadap nilai perusahaan. Akuntabilitas, 10(2), 333-348. https://doi.org/10.15408/akt.v10i2.4649.

Irawan, F., and Turwanto, T. (2020). The effect of tax avoidance on firm value with tax risk as moderating variable. Test Engineering and Management, 83(March-April), 96969707.

Jananto, A. E., and Firmansyah, A. (2019). The effect of bonuses, cost of debt, tax avoidance, and corporate governance on financial reporting aggressiveness: evidence from Indonesia. International Journal of Innovation, Creativity and Change, 7(5), 280-302.

Jiraporn, P., Jiraporn, N., Boeprasert, A., and Chang, K. (2014). Does corporate social responsibility (csr) improve credit ratings ? evidence from geographic identification. Financial Management, Fall, 505-531. https://doi.org/10.1111/fima.12044.

Kim, J., and Charlie, B. (2013). Real earning management and cost of capital. Journal of Accounting and Public Policy, 32(6), 518-543. https://doi.org/10.1016/j.jaccpubpol.2013.08.002.

Kling, G., Volz, U., Murinde, V., and Ayas, S. (2021). The impact of climate vulnerability on firms' cost of capital and access to finance. World Development, 137, 1-11. https://doi.org/10.1016/j.worlddev.2020.105131.

Kovermann, J. H. (2018). Tax avoidance, tax risk and the cost of debt in a bank-dominated economy. Managerial Auditing Journal, 33(8-9), 683-699. https://doi.org/10.1108/MAJ-12-2017-1734.

Kubick, T. R., and Lockhart, G. B. (2017). Corporate tax aggressiveness and the maturity structure of debt. Advances in Accounting, 36, 50-57. https://doi.org/10.1016/j.adiac.2016.10.001. 
Laguir, I., Staglianò, R., and Elbaz, J. (2015). Does corporate social responsibility affect corporate tax aggressiveness? Journal of Cleaner Production, 107, 662-675. https://doi.org/10.1016/j.jclepro.2015.05.059.

Lietz, G. (2013). Tax avoidance vs tax aggressiveness: A unifying conceptual framework. In Working Paper. https://doi.org/10.2139/ssrn.2363828.

Lin, X., Liu, M., So, S., and Yuen, D. (2019). Corporate social responsibility, firm performance and tax risk responsibility. Managerial Auditing Journal, 34(9), 11011130. https://doi.org/10.1108/MAJ-04-2018-1868.

Nuryatno, M., Nazir, N., dan Rahmayanti, M. (2019). Hubungan antara pengungkapan, informasi asimetri dan biaya modal. Jurnal Informasi, Perpajakan, Akuntansi, Dan Keuangan Publik, 2(1), 9. https://doi.org/10.25105/jipak.v2i1.4424.

Oral, C., and Akkaya, G. C. (2015). Cash flow at risk: a tool for financial planning (Vol. 23). https://doi.org/10.1016/S2212-5671(15)00358-5.

Pérez, A. (2015). Corporate reputation and CSR reporting to stakeholders: Gaps in the literature and future lines of research. Corporate Communications, 20(1), 11-29. https://doi.org/10.1108/CCIJ-01-2014-0003.

Pradipta, D. H., dan Supriyadi, S. (2015). Pengaruh corporate social responsibility (csr), profitabilitas, leverage, dan komisaris independen terhadap praktik penghindaran pajak. http://lib.ibs.ac.id/materi/Prosiding/SNA XVIII/makalah/123.pdf

Rachmawati, N. A., and Martani, D. (2017). Book-tax conformity level on the relationship between tax reporting aggressiveness and financial reporting aggressiveness. Australasian Accounting, Business and Finance Journal, 11(4), 86-101.

Rokhlinasari, S. (2015). Teori-teori dalam pengungkapan informasi corporate social responbility perbankan. Al-Amwal: Jurnal Ekonomi Dan Perbankan Syari'ah, 7(1), 1-11. https://doi.org/10.24235/amwal.v7i1.217.

Shin, H. J., and Woo, Y. S. (2018). The effect of tax avoidance on cost of debt capital: Evidence from Korea. South African Journal of Business Management, 48(4), 83-89. https://doi.org/10.4102/sajbm.v48i4.45.

Sikes, S. A., and Verrecchia, R. E. (2020). Aggregate corporate tax avoidance and cost of capital. https://doi.org/10.2139/ssrn.3662733.

Suto, M., and Takehara, H. (2017). CSR and cost of capital: Evidence from Japan. Social Responsibility Journal, 13(4), 798-816. https://doi.org/10.1108/SRJ-10-2016-0170

Wardani, D. K., Putriane, S. W., Puspitaningsih, E., Astuti, A. Y., dan Mutorikoh, N. (2019). Dampak riil penghindaran pajak pada perusahaan manufaktur di Bursa Efek Indonesia. Jurnal Akuntansi \& Manajemen Akmenika, 16(2), 255-270. https://doi.org/10.31316/akmenika.v17i1.678.

Whait, R. B., Christ, K. L., Ortas, E., and Burritt, R. L. (2018). What do we know about tax aggressiveness and corporate social responsibility? An integrative review. Journal of Cleaner Production, 204, 542-552. https://doi.org/10.1016/j.jclepro.2018.08.334.

Widodo, T. T., dan Firmansyah, A. (2021). Does investors respond to tax avoidance and tax risk? Bina Ekonomi, 25(1), 23-40. https://doi.org/10.26593/be.v25i1.5123.23-40.

Yeh, C. C., Lin, F., Wang, T. S., and Wu, C. M. (2020). Does corporate social responsibility affect cost of capital in China? Asia Pacific Management Review, 25(1), 1-12. https://doi.org/10.1016/j.apmrv.2019.04.001 